\title{
THE INFLUENCE OF TRACTOR EXPLOITATION TIME ON THE GENERATED NOISE LEVEL
}

\author{
Željko Barač, Ivan Plaščak, Tomislav Jurić, Mladen Jurišić
}

Preliminary notes

The paper presents research results on noise levels in 2010 and 2013 in accordance with the prescribed standards HRN ISO 6393, HRN ISO 6395, HRN ISO 6394, HRN ISO 6396, and HRN ISO 5131. The measurements were performed on the test fields of the Belje holding company. The research was conducted on 3 FENDT tractors, model 410 in order to determine the increase of generated noise with regard to the exploitation time of the tractors. The results show that none of the tractors included in the research generated higher levels of noise than the $80 \mathrm{~dB}$ allowed by standards. Generally, the hypotheses were proved that exploitation "older" tractors would generate higher noise levels compared to exploitation "younger" tractors.

Keywords: agricultural tractor; external noise; internal noise

Utjecaj trajanja eksploatacije traktora na proizvedenu razinu buke

Prethodno priopćenje Rad prikazuje dvogodišnje (2010. i 2013.) rezultate istraživanja razine buke u skladu s propisanim normama HRN ISO 6393, HRN ISO 6395, HRN ISO 6394, HRN ISO 6396, and HRN ISO 5131. Mjerena su izvedena na pokusnim površinama tvrtke Belje d.d. Istraživanje je provedeno na 3 FENDT traktora, model $410 \mathrm{~s}$ ciljem utvrđivanja povećanja proizvedene buke u odnosu na vrijeme koje su traktori proveli u eksploataciji. Dobiveni rezultati pokazuju kako niti jedan istraživani traktor nije proizveo višu razinu buke od $80 \mathrm{~dB}$ koja je normama dozvoljena. Općenito, hipoteza kako će eksploatacijski gledano "stariji" traktori proizvoditi višu razinu buke u odnosu na eksploatacijski gledano "mlađe" traktore je dokazana.

Ključne riječi: poljoprivredni traktor; unutarnja buka; vanjska buka

\section{Introduction}

Noise hampers communication and the reception of alarm signals. It causes fatigue, diminishes concentration, causes orientation disturbances and reduces safety at work (i.e. it permanently impairs hearing). It results in pupil dilation, a decrease of skin elasticity, an increase of blood pressure, a change in breathing, and an increase of muscle tension. Therefore, it can be said that noise is any unwanted sound.

Ref. [1] measured the noise level on a MASEY FERGUSON 399 tractor with and without a cab at 1500, 1750 , and 2000 revolutions per minute. The tractor without a cab had the highest measured noise of $88 \mathrm{~dB}$ at a revolution per minute of 2000 , whereas the tractor with a cab reached the highest noise level of $72 \mathrm{~dB}$ at a revolution per minute of 2000 . The latter value points to a significantly decreased noise levels compared to the tractor with a cab. It was obvious that noise levels are lower for a tractor equipped with a cab, which facilitates better working conditions. The results of measured noise levels ranging from $62,1 \mathrm{~dB}$ to $87,4 \mathrm{~dB}$ taking place when different tasks were performed by a tractor with powers ranging from $96 \mathrm{~kW}$ to $227 \mathrm{~kW}$, [2]. The same author established that an average measured noise level does not negatively affect tractor operators.

According to [3] noise levels for a FENDT 930 tractor were measured in the cab at full load (i.e. ploughing) and it was 77,5 dB. Apart from internal noise, the external noise at a distance of $7,5 \mathrm{~m}$ from the longitudinal tractor axis at a height of $1 \mathrm{~m}$ was measured. A lower noise level of $82 \mathrm{~dB}$ was measured on the left side of the tractor, whereas the higher value of $88,9 \mathrm{~dB}$ was measured on the right side. The underlying reason for a higher noise level on the right tractor side is the exhaust pipe located on that side. Similar measurement of both external and internal noise levels but for the YTO 454 tractor showed $85,3 \mathrm{~dB}$ on the side where the exhaust resonance chamber was located and $84,2 \mathrm{~dB}$ one the opposite side. In the case when windows and doors were open, it reached 89,2 dB [4]. Ref. [5] pointed out that the measured noise level for FENDT tractors did not exceed $80 \mathrm{~dB}$. However, to reach this value all owners who possess vehicles or buildings should pay attention to maintenance and repair which depends on the noise level with the general aim of protecting operators against noise. Noise has been determined to cause a range of problems that have a negative influence. This is particularly true for tractor operators, who perform a demanding and responsible job. Ref. [6] tested an IMT 549 tractor. The highest level of daily or weekly noise exposure is $85 \mathrm{~dB}$. At the same time the highest $\mathrm{C}$-value noise should not exceed $L_{\text {Cpeak }}=140 \mathrm{~dB}$. The measured noise level of 81 $\mathrm{dB}$ in a tractor cab can be claimed not to cause danger to hearing because of the noise level not exceeding the daily or weekly levels of $85 \mathrm{~dB}$. A noise level measurement for a JOHN DEERE 8520 tractor at 4 different load levels established that all noise levels were under the allowed values [7]. The same authors claim that established noise levels make the work comfortable during all working hours and cause no fatigue.

Noise levels indicate a right choice of engine, resonance chamber, and cab damping capabilities, which can in turn facilitate a general on-site efficiency improvement. The measured noise levels in cabs are under the prescribed values in EU countries. According to [8] the noise in hydroelectric power plants directly affects the employees if its intensity is higher than permitted values, according to the legal regulations. The maximum effect of noise reduction in the first stage will be reached to set the absorbing lining and by direct isolation of turbine pipes. Ref. [9] argue that noise is related to regular maintenance of agricultural machinery.

The aim of this research was to determine internal and external noise levels for the same tractor type but with a different number of working hours and to 
determine potential dependency. The hypothesis was that there would be significant differences regarding the measured noise levels depending on tractor exploitation time.

\section{Materials and methods}

Noise was measured for 3 FENDT 410 tractors. Prior to measurement the tractors performed the same tasks. The tractors had about the same number of working hours in 2010. The tractors T1, T2, and T3 had 5580, 6584, and 7574 working hours, respectively. The number of working hours between the measurements in 2010 and 2013 for the tractors T1, T2, and T3 was 14 578, 14 433, and 14 443, respectively. According to the data, it can be established that the tractors were in operation for a similar number of hours. Hereinafter, tractors with a lower number of working hours will be called "younger" or (1) in Tab. 1, 3, 5 and 7, and those with a greater number of working hours "older" tractors or (2) in Tab. 1, 3, 5 and 7.

The measurements of noise levels were performed in 2010 and repeated in 2013 according to the prescribed norms for noise measurement generated by a tractor into environment $[10,11]$, as well as for noise measurement generated by a tractor in the operator's cab $[12,13,14]$. They were performed on a test field of the Belje holding company. The measuring procedure regarding tractor generated noise into the environment was performed in accordance with the [10] that stipulates that noise be measured when the tractor is standing, as well as in accordance with the [11] that stipulates that noise be measured when the tractor is moving.

As regards [11], the tractor moved along a 14-metre long line from point $\mathrm{A}$ to point $\mathrm{B}$ in a forward direction, as well as along a 14-metre line from point $B$ to point $A$ in a backward direction at a speed of $7,5 \mathrm{~km} / \mathrm{h}$. As regards [10], 3 measurements were taken for each point at 1100 $\mathrm{min}^{-1}, 1800 \mathrm{~min}^{-1}$ and $2200 \mathrm{~min}^{-1}$. The measurement of tractor generated noise in the cab was performed 3 times on both the left and right side of the operator at 1100 $\min ^{-1}, 1800 \mathrm{~min}^{-1}$ and $2200 \mathrm{~min}^{-1}$. In accordance with [13], the measurements were performed on both the left and right operator's side while the tractor was moving along the 14-metre line from point $\mathrm{A}$ to point $\mathrm{B}$ in a forward direction, as well as backwards from point $\mathrm{B}$ to point $A$ at a speed of $7,5 \mathrm{~km} / \mathrm{h}$. Ref. [14] stipulates that the position of the device relative to a reference point be the operator's seat, which is from the middle of the operator's head to the seat level at a height $790^{ \pm 20} \mathrm{~mm}$. It has to be at a distance of $200^{ \pm 20} \mathrm{~mm}$ from the middle part of the head both on the left and the right side. Each point of measurement for both internal and external noise levels was measured 3 times in thirty-second intervals. Based on these measurements an average equivalent of permanent noise level was established.

The measurements were performed using a METREL device, type Multinorm MI 6201 EU equipped by a sound probe (microphone class B) produced by the same manufacturer and resulted in the following values:

- $L_{\mathrm{eq}}$ - time average sound level or equivalent continuous sound level is measured on both channels. This is probably the most important and frequently used measurement. It measures the average of a sound level over the whole duration of measurement,

- $L_{\text {Fmin }}$ - minimum time weighted sound level is measured on both channels. It is the minimum of $L_{\mathrm{F}}$ over the whole duration of measurement,

- $L_{\text {Fmax }}$ - maximum time weighted sound level is measured on both channels. It is the maximum of $L_{\mathrm{F}}$ over the whole duration of measurement.

The measured values were statistically analysed using an application for statistical analysis in MS Office Excel 2010, and IBM SPSS Statistics v.19.0.1. The paper shows descriptive statistical values and analysis of variance (ANOVA).

\section{Results and discussion}

\subsection{A parallel representation of external noise mean values}

Fig. 1 shows the dependency between the external noise level and tractor age. The measurement of noise level in 2010 established as follows: an T3 tractor produced the highest permanent equivalent mean level of noise $\left(L_{\mathrm{eq}}\right)$ measured at $1100 \mathrm{~min}^{-1}$ which was $64,5 \mathrm{~dB}$, at $1800 \mathrm{~min}^{-1}$ it was $68,3 \mathrm{~dB}$, at $2200 \mathrm{~min}^{-1}$ the highest permanent equivalent mean level of noise was produced by the $\mathrm{T} 2$ tractor $(71,8 \mathrm{~dB})$ followed by the $\mathrm{T} 1$ tractor $(70,5 \mathrm{~dB})$. The lowest permanent equivalent mean level of noise was produced by the T3 tractor $(69,9 \mathrm{~dB})$. The 2013 measurements resulted in the following values: the highest permanent equivalent mean noise level of $65,5 \mathrm{~dB}$ was produced by the T3 tractor at $1100 \mathrm{~min}^{-1}$. The T2 tractor produced noise levels of $69,18 \mathrm{~dB}$ and $70,7 \mathrm{~dB}$ at $1800 \mathrm{~min}^{-1}$ and $2200 \mathrm{~min}^{-1}$, respectively. The lowest permanent equivalent mean noise level of $70,1 \mathrm{~dB}$ was measured for the $\mathrm{T} 1$ tractor.

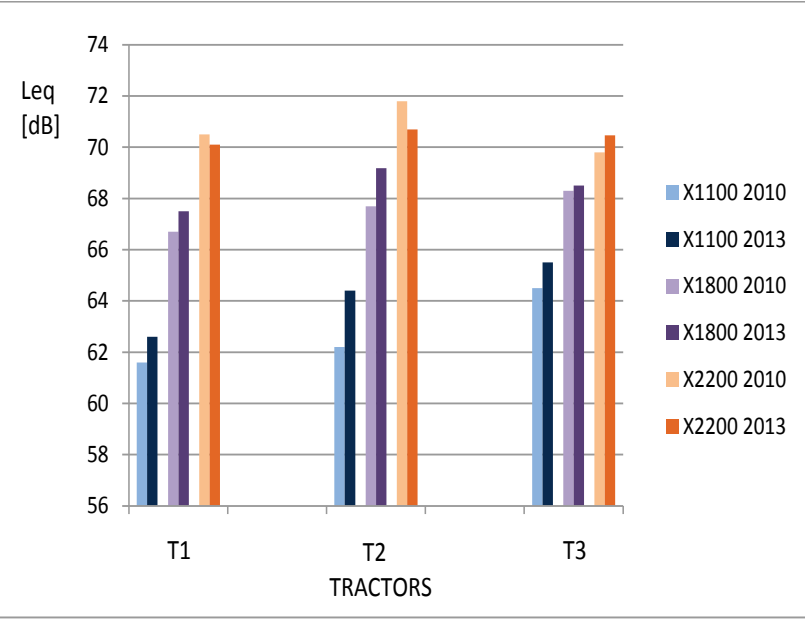

Figure 1 A parallel representation of the mean noise values in standing

Fig. 2 depicts the noise measurement in 2010. The highest equivalent permanent mean level of noise for the $\mathrm{T} 3$ tractor was $71,4 \mathrm{~dB}$. It was followed by the T1 tractor which produced a noise of $70,5 \mathrm{~dB}$, and the $\mathrm{T} 2$ tractor which produced the lowest equivalent permanent mean noise level of $68,7 \mathrm{~dB}$. The values in 2013 were the following: the $\mathrm{T} 2$ tractor produced a noise of $70,65 \mathrm{~dB}$, the T3 tractor $70,63 \mathrm{~dB}$, and the lowest noise level of 68,8 $\mathrm{dB}$ was produced by the $\mathrm{T} 1$ tractor. 


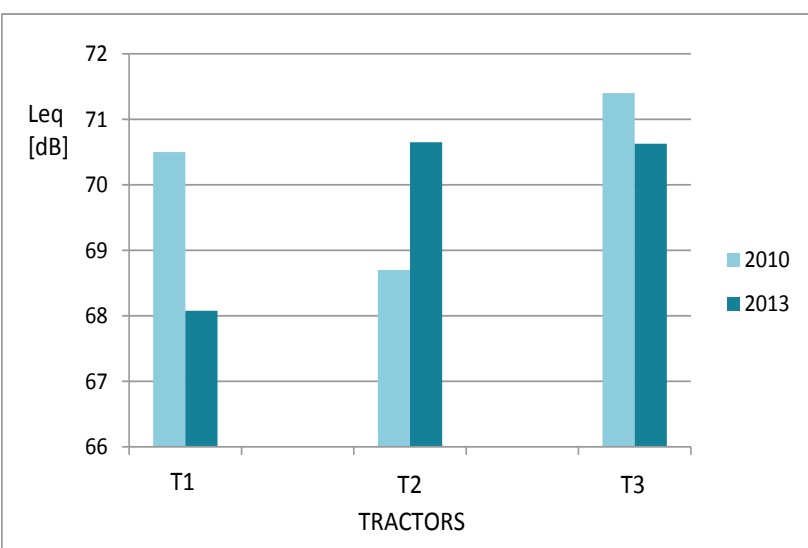

Figure 2 Parallel representations of the mean external noise values in moving

\subsection{A parallel representation of the mean values established in the operator's working space}

Fig. 3 shows an only partly proved hypothesis. In 2010 the highest equivalent permanent mean noise level was produced by the $\mathrm{T} 3$ tractor regardless of the researched modes of work: the measured values at 1100 $\min ^{-1}, 1800 \mathrm{~min}^{-1}$ and $2200 \mathrm{~min}^{-1}$ were $66,5 \mathrm{~dB}, 71,7 \mathrm{~dB}$, and 70,9 dB, respectively. The lowest equivalent permanent mean noise level regardless of the work mode was produced by the T2 tractor: the values measured at $1100 \mathrm{~min}^{-1}, 1800 \mathrm{~min}^{-1}$ and $2200 \mathrm{~min}^{-1}$ were $66,43 \mathrm{~dB}$, 69,45 , and $71,66 \mathrm{~dB}$, respectively.

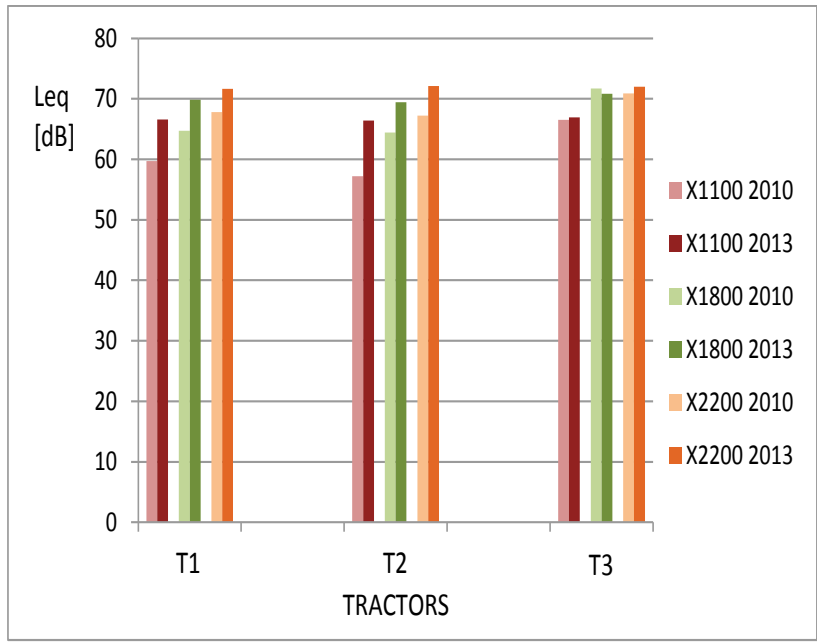

Figure 3 Parallel representations of the mean noise values in standing
Fig. 4 depicts the highest equivalent permanent mean noise level measured in 2010. For the tractors T3, T1, and T2 it was $71,5 \mathrm{~dB}, 68,55 \mathrm{~dB}$ and $64,5 \mathrm{~dB}$, respectively. Therefore, the lowest equivalent permanent mean noise level was produced by the $\mathrm{T} 2$ tractor, whereas the highest value was produced by the $\mathrm{T} 3$ tractor. A repetition of the measurements in 2013 revealed the highest equivalent permanent mean noise level of $75,12 \mathrm{~dB}$ for the $\mathrm{T} 3$ tractor. The $\mathrm{T} 1$ tractor produced a $74,71 \mathrm{~dB}$ noise level, whereas the lowest equivalent permanent mean noise level of 71,3 $\mathrm{dB}$ was produced by the $\mathrm{T} 2$ tractor.

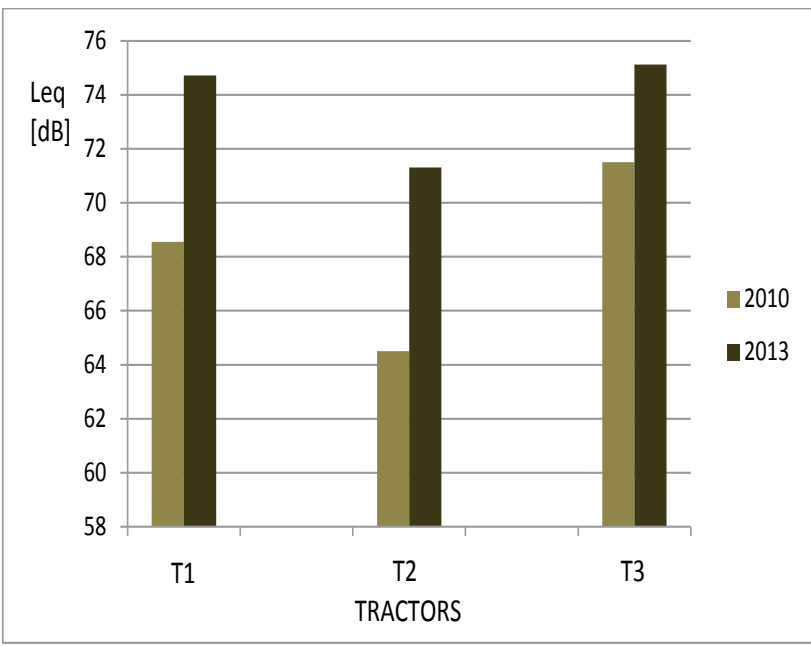

Figure 4 Parallel representations of the mean noise values in moving

\subsection{A parallel statistical representation of the measured noise levels}

Tab. 1 reveals that at $1100 \mathrm{~min}^{-1}$ the standard error of 0,3306 is lower in the case of younger tractors (1). On the contrary, the standard error of 0,3598 is higher for the older tractors (2). A lower standard error of 0,2998 for older tractors (2) and higher standard error of 0,4023 was determined for younger tractors (1) at $1800 \mathrm{~min}^{-1}$. At $2200 \mathrm{~min}^{-1}$ the standard error of 0,2708 is lower for older tractors (2), whereas a significantly higher standard error of 0,4151 was determined for younger tractors (1).

Tab. 2 reveals a statistically significant difference established through the variance analysis as regards the mean values for the tractors. It is obvious that older tractors produce higher noise levels at $1100 \mathrm{~min}^{-1}$ in standing (2013).

Table 1 Descriptive statistics of mean values of external noise when standing

\begin{tabular}{|c|c|c|c|c|c|c|c|c|c|}
\hline & \multirow{2}{*}{$N$} & \multirow{2}{*}{$\begin{array}{c}\text { Mean } \\
L_{\text {eq }}, \mathrm{dB}\end{array}$} & \multirow{2}{*}{$\begin{array}{c}\text { Std. } \\
\text { Deviation } \\
\end{array}$} & \multirow{2}{*}{$\begin{array}{c}\text { Coef. of } \\
\text { Variation }\end{array}$} & \multirow{2}{*}{ Std. Error } & \multicolumn{2}{|c|}{$95 \%$ Confidence Interval for Mean } & \multirow{2}{*}{ Min } & \multirow{2}{*}{$\operatorname{Max}$} \\
\hline & & & & & & Lower Bound & Upper Bound & & \\
\hline \multicolumn{10}{|c|}{$1100 \mathrm{~min}^{-1}$} \\
\hline 1 & 36 & 62,819 & 1,9837 & 3,1578 & 0,3306 & 62,148 & 63,490 & 59,2 & 66,4 \\
\hline 2 & 36 & 64,200 & 2,1591 & 3,3630 & 0,3598 & 63,469 & 64,930 & 59,8 & 69,2 \\
\hline$\sum$ & 72 & 63,509 & 2,1728 & 3,4212 & 0,2560 & 62,999 & 64,020 & 59,2 & 69,2 \\
\hline \multicolumn{10}{|c|}{$1800 \mathrm{~min}^{-1}$} \\
\hline 1 & 36 & 67,647 & 2,4137 & 3,5680 & 0,4022 & 66,830 & 68,463 & 63,3 & 70,5 \\
\hline 2 & 36 & 68,416 & 1,7991 & 2,6296 & 0,2998 & 67,807 & 69,025 & 64,6 & 71,0 \\
\hline$\sum$ & 72 & 68,031 & 2,1488 & 3,1586 & 0,2532 & 67,527 & 68,536 & 63,3 & 71,0 \\
\hline \multicolumn{10}{|c|}{$2200 \mathrm{~min}^{-1}$} \\
\hline 1 & 36 & 70,805 & 2,4908 & 3,5179 & 0,4151 & 69,962 & 71,648 & 66,2 & 74,5 \\
\hline 2 & 36 & 70,186 & 1,6251 & 2,3155 & 0,2708 & 69,636 & 70,736 & 67,0 & 72,6 \\
\hline$\sum$ & 72 & 70,495 & 2,1113 & 2,9950 & 0,2488 & 69,999 & 70,992 & 66,2 & 74,5 \\
\hline
\end{tabular}


Table 2 Analysis of variance (ANOVA)

\begin{tabular}{|l|c|c|c|c|c|}
\hline \multicolumn{7}{|c|}{$\begin{array}{c}\text { Sum of } \\
\text { Squares }\end{array}$} & df & $\begin{array}{c}\text { Mean } \\
\text { Square }\end{array}$ & F & Sig. \\
\hline \multicolumn{7}{|c|}{1100 min $^{-1}$} \\
$\begin{array}{l}\text { Between } \\
\text { Groups }\end{array}$ & 34,307 & 1 & 34,307 & 7,981 & 0,006 \\
\hline $\begin{array}{l}\text { Within } \\
\text { Groups }\end{array}$ & 300,896 & 70 & 4,299 & & \\
\hline$\sum$ & 335,203 & 71 & & & \\
\hline \multicolumn{7}{|c|}{1800 min $^{-1}$} & 2,352 & 0,130 \\
\hline $\begin{array}{l}\text { Between } \\
\text { Groups }\end{array}$ & 10,657 & 1 & 10,657 & & \\
\hline $\begin{array}{l}\text { Within } \\
\text { Groups }\end{array}$ & 317,200 & 70 & 4,531 & & \\
\hline$\sum$ & 327,857 & 71 & & & \\
\hline \multicolumn{7}{|c|}{2200 min $^{-1}$} & & \\
\hline $\begin{array}{l}\text { Between } \\
\text { Groups }\end{array}$ & 6,907 & 1 & 6,907 & 1,562 & 0,216 \\
\hline $\begin{array}{l}\text { Within } \\
\text { Groups }\end{array}$ & 309,602 & 70 & 4,423 & & \\
\hline$\sum$ & 316,509 & 71 & & & \\
\hline
\end{tabular}

Tab. 3 shows again that the standard error of 0,4116 is lower for older tractor (2), whereas younger tractors have a higher standard error of 0,4943 .

No statistically significant difference was established with regard to the mean values of measured noise for the research tractors through the variance analysis, as shown in Tab. 4.

Tab. 5 depicts again at $1100 \mathrm{~min}^{-1}, 1800 \mathrm{~min}^{-1}$ and $2200 \mathrm{~min}^{-1}$ the standard error is lower in older tractors (2).

Tab. 6 shows a lower standard error of 0,6001 for older tractors (2). The standard error of 1,0319 for younger tractors is significantly higher.

Tab. 7 depicts a statistically significant difference obtained through the variance analysis regarding the mean values of measured noise. It shows a higher level of noise measured at $1100 \mathrm{~min}^{-1}$ in the standing position in the case of older tractors (2013). It is obvious that the level of produced noise in older tractors at $1800 \mathrm{~min}^{-1}$ in standing is higher (2013). Also it can be seen that the level of generated noise in standing at $2200 \mathrm{~min}^{-1}$ also has a higher level for older tractors.

Table 3 Descriptive statistics of mean values of external noise in moving

\begin{tabular}{|c|c|c|c|c|c|c|c|c|c|}
\hline & \multirow{2}{*}{$N$} & \multirow{2}{*}{$\begin{array}{c}\text { Mean } \\
L_{\mathrm{eq}}, \mathrm{dB}\end{array}$} & \multirow{2}{*}{$\begin{array}{c}\text { Std. } \\
\text { Deviation }\end{array}$} & \multirow{2}{*}{$\begin{array}{c}\text { Coef. of } \\
\text { Variation }\end{array}$} & \multirow{2}{*}{ Std. Error } & \multicolumn{2}{|c|}{$95 \%$ Confidence Interval for Mean } & \multirow{2}{*}{ Min } & \multirow{2}{*}{ Max } \\
\hline & & & & & & Lower Bound & Upper Bound & & \\
\hline 1 & 24 & 70,245 & 2,4220 & 3,4478 & 0,4943 & 69,223 & 71,268 & 66,2 & 74,8 \\
\hline 2 & 24 & 69,791 & 2,0165 & 2,8893 & 0,4116 & 68,940 & 70,643 & 65,6 & 74,0 \\
\hline$\sum$ & 48 & 70,018 & 2,2165 & 3,1657 & 0,3199 & 69,375 & 70,662 & 65,6 & 74,8 \\
\hline
\end{tabular}

Table 4 Analysis of variance (ANOVA)

\begin{tabular}{|l|c|c|c|c|c|}
\hline & Sum of Squares & df & Mean Square & F & Sig. \\
\hline Between Groups & 2,477 & 1 & 2,477 & 0,499 & 0,484 \\
\hline Within Groups & 228,447 & 46 & 4,966 & & \\
\hline$\sum$ & 230,924 & 47 & & & \\
\hline
\end{tabular}

Table 5 Descriptive statistics of mean values of internal noise in standing

\begin{tabular}{|c|c|c|c|c|c|c|c|c|c|}
\hline & \multirow{2}{*}{$N$} & \multirow{2}{*}{$\begin{array}{c}\text { Mean } \\
L A_{\text {eq }}, \mathrm{dB}\end{array}$} & \multirow{2}{*}{$\begin{array}{c}\text { Std. } \\
\text { Deviation }\end{array}$} & \multirow{2}{*}{$\begin{array}{c}\text { Coef. of } \\
\text { Variation }\end{array}$} & \multirow{2}{*}{ Std. Error } & \multicolumn{2}{|c|}{$95 \%$ Confidence Interval for Mean } & \multirow[b]{2}{*}{ Min } & \multirow{2}{*}{ Max } \\
\hline & & & & & & Lower Bound & Upper Bound & & \\
\hline \multicolumn{10}{|c|}{$1100 \mathrm{~min}^{-1}$} \\
\hline 1 & 18 & 61,177 & 4,1716 & 6,8189 & 0,9832 & 59,103 & 63,252 & 56,9 & 68,1 \\
\hline 2 & 18 & 66,699 & 0,7817 & 1,1720 & 0,1842 & 66,311 & 67,088 & 65,6 & 68,2 \\
\hline$\sum$ & 36 & 63,938 & 4,0731 & 6,3704 & 0,6788 & 62,560 & 65,317 & 56,9 & 68,2 \\
\hline \multicolumn{10}{|c|}{$1800 \min ^{-1}$} \\
\hline 1 & 18 & 66,988 & 3,6091 & 5,3876 & 0,8506 & 65,194 & 68,783 & 63,3 & 73,0 \\
\hline 2 & 18 & 70,034 & 2,6161 & 3,7355 & 0,6166 & 68,733 & 71,335 & 65,9 & 74,3 \\
\hline$\sum$ & 36 & 68,511 & 3,4693 & 5,0639 & 0,5782 & 67,337 & 69,685 & 63,3 & 74,3 \\
\hline \multicolumn{10}{|c|}{$2200 \mathrm{~min}^{-1}$} \\
\hline 1 & 18 & 68,672 & 1,8093 & 2,6348 & 0,4264 & 67,772 & 69,572 & 66,7 & 71,2 \\
\hline 2 & 18 & 71,937 & 1,5172 & 2,1090 & 0,3576 & 71,183 & 72,692 & 69,7 & 74,3 \\
\hline$\sum$ & 36 & 70,305 & 2,3344 & 3,3207 & 0,3891 & 69,515 & 71,095 & 66,7 & 74,3 \\
\hline
\end{tabular}

Table 6 Descriptive statistics of mean values of internal noise in moving

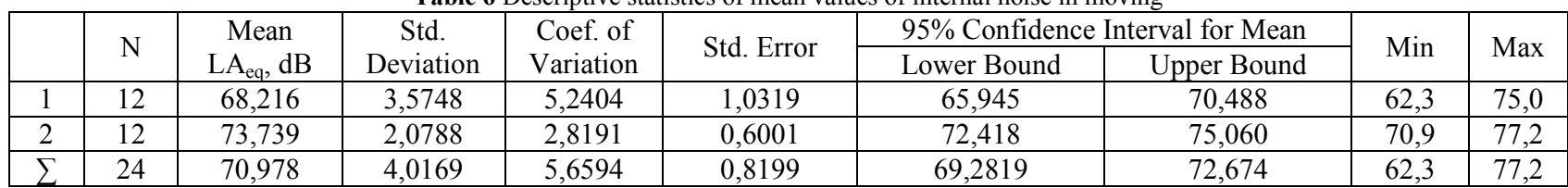

A statistically significant difference with regard to the mean values of measured noise was determined through the variance analysis. Tab. 8 shows that the level of produced noise in moving is higher for older tractors (2013). 
Table 7 Analysis of variance (ANOVA)

\begin{tabular}{|l|c|c|c|c|c|}
\hline \multicolumn{7}{|c|}{ Table 7 Analysis of variance (ANOVA) } \\
\begin{tabular}{|l|c|c|c|c|c|}
\hline Sum of \\
Squares
\end{tabular} & $d f$ & $\begin{array}{c}\text { Mean } \\
\text { Square }\end{array}$ & $F$ & Sig. \\
\hline $\begin{array}{l}\text { Between } \\
\text { Groups }\end{array}$ & 274,436 & 1 & 274,436 & 30,469 & 0,000 \\
\hline $\begin{array}{l}\text { Within } \\
\text { Groups }\end{array}$ & 306,241 & 34 & 9,007 & & \\
\hline$\sum$ & 580,676 & 35 & & & \\
\hline \multicolumn{7}{|c|}{$1800 \min ^{-1}$} & 8,404 & 0,007 \\
\hline $\begin{array}{l}\text { Between } \\
\text { Groups }\end{array}$ & 83,489 & 1 & 83,489 & & \\
\hline $\begin{array}{l}\text { Within } \\
\text { Groups }\end{array}$ & 337,791 & 34 & 9,935 & & \\
\hline$\sum$ & 421,280 & 35 & & & \\
\hline \multicolumn{7}{|c|}{$2200 \min ^{-1}$} & 95,979 & 34,427 & 0,000 \\
\hline $\begin{array}{l}\text { Between } \\
\text { Groups }\end{array}$ & 95,979 & 1 & 95,979 & & \\
\hline $\begin{array}{l}\text { Within } \\
\text { Groups }\end{array}$ & 94,790 & 34 & 2,788 & & \\
\hline$\sum$ & 190,769 & 35 & & & \\
\hline
\end{tabular}

Table 8 Analysis of variance (ANOVA)

\begin{tabular}{|l|c|c|c|c|c|}
\hline & $\begin{array}{c}\text { Sum of } \\
\text { Squares }\end{array}$ & $d f$ & $\begin{array}{c}\text { Mean } \\
\text { Square }\end{array}$ & $F$ & Sig. \\
\hline $\begin{array}{l}\text { Between } \\
\text { Groups }\end{array}$ & 183,018 & 1 & 183,018 & 21,404 & 0,000 \\
\hline $\begin{array}{l}\text { Within } \\
\text { Groups }\end{array}$ & 188,113 & 22 & 8,551 & & \\
\hline$\sum$ & 371,131 & 23 & & & \\
\hline
\end{tabular}

\section{Conclusion}

The aim of the research was to determine the external and internal noise produced by a tractor in the working area and the operator's cab in dependence on the tractor exploitation time (i.e. the number of working hours). Generally speaking, which is also supported by the statistical tables depicting the mean values of external noise in standing, older tractors produced higher noise levels at $1100 \mathrm{~min}^{-1}, 1800 \mathrm{~min}^{-1}$ as well as $1800 \mathrm{~min}^{-1}$, whereas younger tractors produced higher noise levels at $2200 \mathrm{~min}^{-1}$. Descriptive statistics points to the fact that mean values of external noise in moving are higher for younger tractors. Additionally, higher mean values of external noise were determined for older tractors in standing regardless of revolutions per minute. Higher levels of internal noise were determined for older tractors with higher amounts of working hours.

The results of the research as regards the noise generated internally both when tractors were standing and moving confirmed the hypothesis that the higher number of working hours causes higher noise levels. As regards the external noise levels at $1100 \mathrm{~min}^{-1}$ and $1800 \mathrm{~min}^{-1}$ the hypothesis was completely confirmed. The measured external noise level at $2200 \mathrm{~min}^{-1}$ in standing and in moving did not confirm the hypothesis. Further research should describe this anomaly. Considering the results and conclusions, in order to decrease noise levels in a tractor cab that has a direct negative influence on the tractor driver, it should be necessary to change rubber seals as well as door seals and any other seals of the researched tractors. Based on the measurements, it can be seen that neither in standing nor in moving at any measurement point was the noise level higher than the allowed $80 \mathrm{~dB}$.
Accordingly, the tractor operators were neither subject to legally prescribed dangerous noise level regardless of the tractor age nor were they subject to any temporary or permanent hearing impairment. In case when higher noise levels than the prescribed $80 \mathrm{~dB}$ occurred, it would be necessary to discover the cause and to protect the operator, who should use the basic means of safety protection.

\section{$5 \quad$ References}

[1] Mofrad, F. E.; Lar, M. B.; Kohan, A. Reduce Noise in the $\mathrm{Cab}$ of the Tractor MF399 Sugar Transport Operation. // Advances in Environmental Biology. 8, 6(2014), pp. 30353038.

[2] Bilski, B. Audible and Infrasonic Noise Levels in the Cabins of Modern Agricultural Tractors - Does the Risk of Adverse, Exposure - Dependent Effects Still Exist. // International Journal of Occupational Medicine and Environmental Health. 26, 3(2013), pp. 488-493. DOI: 10.2478/s13382-013-0116-0

[3] Savin, L.; Nikolić, R.; Simikić, M.; Furman, T.; Tomić, M. Research Results on a FENDT 930 Tractor. // Tractors and Power Machines. 11, 5(2006), pp. 118-124.

[4] Savin, L.; Tomić, M.; Simikić, M.; Mago, L. Research on the Possibility of YTO 454 Tractor Homologation. // Tractors and Power Machines. 16, 2(2011), pp. 37-42.

[5] Barač, Ž. The impact of age on tractors produced noise. // Master thesis, University of Josip Juraj Strossmayer in Osijek, Faculty of Agriculture, Croatia, 2013.

[6] Goglia, V.; Đukić, I.; Gospodarić, Z.; Filipović, D. Some Ergonomic Features of the Cab of an IMT 549 Tractor. // Actual Tasks on Agricultural Engineering, Proceedings of the $35^{\text {th }}$ International Symposium on Agricultural Engineering / Opatija, 2007, pp. 381-391.

[7] Goglia, V.; Gospodarić, Z.; Beljo-Lučić, R.; Đukić, I. Some Ergonomic Features of the Cab of a JOHN DEERE 8520 Tractor. // Actual Tasks on Agricultural Engineering, Proceedings of the $33^{\text {rd }}$ International Symposium on Agricultural Engineering / Opatija, 2005, pp. 99-110.

[8] Trbojević, N.; Ikonić, M.; Džambas, I. Description for analysing and model of noise reduction in the turbine facility of hydroelectric power plant. // Engineering Review. 29, 2(2009), pp. 63-68.

[9] Jurić, T.; Šumanovac, L.; Heffer, G.; Emert, R. Construction Features of Agricultural Tractors with Regard to Ergonomic Demands. // Strojarstvo. 39, 5(1997), pp. 209-213.

[10] HZN. Acoustics - Measurement of exterior noise emitted by earth - moving machinery - Stationary test conditions, HRN ISO 6393. Croatian Standards Institute, Zagreb, 2000.

[11] HZN. Acoustics - Measurement of exterior noise emitted by earth - moving machinery - Dynamic test conditions, HRN ISO 6395. Croatian Standards Institute, Zagreb, 2000.

[12] HZN. Acoustics - Measurement at the operator's position of airborne noise emitted by earth - moving machinery Stationary test conditions, HRN ISO 6394. Croatian Standards Institute, Zagreb, 2000.

[13] HZN. Acoustics - Measurement of noise emitted by earth moving machinery at the operator's position - Simulated work cycle test condition, HRN ISO 6396. Croatian Standards Institute, Zagreb, 2000.

[14] HZN (2000). Acoustics - Tractors and machinery for agriculture and forestry - Measurement of noise at the operator's position - Survey method, HRN ISO 5131. Croatian Standards Institute, Zagreb, 2000. 


\section{Authors' addresses}

Željko Barač, MSc, Assistant

Faculty of Agriculture,

Kralja P. Svačića 1d, 31000 Osijek, Croatia

E-mail: zbarac@pfos.hr

Ivan Plaščak, PhD, Assistant Professor

Faculty of Agriculture,

Kralja P. Svačića 1d, 31000 Osijek, Croatia

E-mail: iplascak@pfos.hr

Tomislav Jurić, PhD, Full Professor

Faculty of Agriculture,

Kralja P. Svačića 1d, 31000 Osijek, Croatia

E-mail: tjuric@pfos.hr

Mladen Jurišić, PhD, Full Professor

Faculty of Agriculture,

Kralja P. Svačića 1d, 31000 Osijek, Croatia

E-mail: mjurisic@pfos.hr 